Jānis Maizītis, $M g$. iur.

LU Juridiskā fakultāte, Latvija

\title{
SODU POLITIKA UN VIENOŠANĀS PROCESS
}

\section{PENAL POLICY AND PLEA-BARGAINING}

\begin{abstract}
Summary
The aim of the present paper is to discuss the concept of policy in the context of criminal procedure. The concept is evaluated and its conformity with the policy of criminal law, penal policy and the policy of criminal procedure is tested throughout the study. The paper includes the definition of politics and compares it to the aims of policy. The author analyses the importance of the procedure of plea bargain within the penal policy and their connection. The policy of criminal procedure is associated with comprehensible criteria during plea-bargaining, considering the accused persons willingness to cooperate.
\end{abstract}

Atslēgvārdi: politika, krimināltiesību politika, sodu politika, kriminālprocesa politika, kritēriji vienošanās procesa saistībai ar sodu politiku

Keywords: politics, criminal policy, penal policy, policy of the criminal procedure, criteria, the connection between the process of plea bargain and penal policies

Katra valsts atbilstoši vēsturiskajai pieredzei, tradīcijām, uzskatiem par tiesību sistēmām un piederību tām likumdošanas kārtībā nosaka noteiktu kārtỉbu, kādā izmeklējamas un iztiesājamas krimināllietas. Latvijā spēkā esošā kriminālprocesuālā kārtība būtiski grozīta 2005. gadā, kad stājās spēkā Kriminālprocesa likums (turpmāk - KPL). ${ }^{1}$ Kardināli jaunu likumu jaunrades procesu pamats parasti ir koncepcijas. Arī KPL projekta pamats bija Kriminālprocesa likuma koncepcija. ${ }^{2}$ Koncepcijas un ilgu diskusiju rezultātā tika formulēts KPL 1. pantā noteiktais kriminālprocesa mērḳis - tiek noteikta tāda kriminālprocesuālā kārtība, kas nodrošina efektīvu Krimināllikuma (turpmāk $\mathrm{KL})^{3}$ normu piemērošanu un krimināltiesisko attiecību taisnīgu noregulējumu bez neattaisnotas iejaukšanās personas dzīvē. Ar šādu uzstādījumu tiek noteikta valsts kriminālprocesuālā politika, kas ir ļoti tuva krimināltiesību politikai. Līdz ar to šādā kontekstā ir vērts diskutēt par to, kas ir politika, kas ir krimināltiesību politika, sodu politika un kriminālprocesuālā politika. Turklāt kādus rezultātus var sasniegt, realizējot visus minētos politiku veidus?

Kriminālprocesa likums: Latvijas Republikas likums. Latvijas Vēstnesis, 11.05.2005. Nr. 74 (3232).

2 Kriminālprocesa likuma koncepcija, 12.06.2001. Jurista Vārds, 26.06.2011., Nr. 20.

3 Krimināllikums: Latvijas Republikas likums. Latvijas Vēstnesis Nr. 199/200 (1260/1261) 08.07.1998. [13.03.2019. red]. 


\section{Vispirms - kas ir politika?}

"Politika" ir ikdienā vietā un nevietā lietots visiem saprotams svešvārds. Vienā no svešvārdu vārdnīcām formulētas dažādās nozīmes: "[fr. politique < lat. < gr. Politikē (epistēmē) 'valsts vadīšanas māksla' < polis 'pilsēta, valsts']. Proti, tā ir pirmā sabiedriskās darbības nozare, kas aptver līdzdalību sabiedrības un valsts veidošanā, valsts vadīšanā un valsts lietu kārtošanā, attiecībā starp dažādām sabiedrības grupām un slāṇiem, dažādām tautām un valstīm. Tās otrajā nozīmē "politika" ir valsts, valdības, partijas vai citas organizācijas svarīgākie centieni, mērḳi, principi, stratēgiskās nostādnes; plānveida pasākumi, kurus noteiktu interešu vārdā veic kāds politiskais spēks (piemēram, partija, partiju koalīcija) vai valsts vara. Treškārt, "politika” ir rīcības līnija, kurss, jebkura stratēgija un taktika. Savukārt tās ceturtajā nozīmē "politika” aptver politisko dzivi un politiskos notikumus. ${ }^{4}$ Uz krimināltiesību un kriminālprocesa politiku noteikti attiecas arī tāds politikas skaidrojums kā valsts lietu kārtošana, valsts mērḳi, principi, stratēgiskās nostādnes, plānveida pasākumi, kurus veic valsts vara, rīcības līnija, jebkura stratēgija un taktika. Politikas saturs tiek formulēts kā koncepcija [no latīnu valodas conceptio - kopums; formulējums] jeb darba vispārīgā iecere, pamatideja. ${ }^{5}$ Politika, protams, ir attiecināma uz dažādām tiesību nozarēm, tomēr Latvijas tiesiskajā kārtībā noteikti nepieciešams izteikties par krimināltiesību politiku un sodu politiku. Diemžēl līdz šim maz ir diskutēts par kriminālprocesuālo politiku, autors uzskata, ka Latvijas kriminālprocesuālā kārtība ir izveidota tāda, ka ir pamats diskusijai arī par kriminālprocesuālo politiku, tās iespējamiem attīstības veidiem un stratēgiju. To apliecina arī KPL struktūra, jo likumā atsevišḳi definēti kriminālprocesa pamatprincipi.

\section{Krimināltiesību politika}

Vispirms ar krimināltiesību politiku autors saprot KL deklarēto soda mērḳi un atsevišķos KL pantos noteiktās soda sankcijas. KL 35. pantā noteikts, ka sods un tā mērkis ir:

“(1) Krimināllikumā paredzētais sods ir piespiedu līdzeklis, ko personai, kura ir vainīga noziedzīga nodarījuma izdarīšanā, šā likuma ietvaros valsts vārdā piespriež tiesa vai likumā paredzētajos gadījumos nosaka prokurors, sastādot priekšrakstu par sodu.

(2) Soda mērkis ir:

1) aizsargāt sabiedrības drošìbu;

2) atjaunot taisnīgumu;

3) sodīt vainīgo personu par izdarīto noziedzīgo nodarījumu;

4) resocializēt sodìto personu;

5) panākt, lai notiesātais un citas personas pildītu likumus un atturētos no noziedzīgu nodarījumu izdarīšanas."

4 Baldunčiks J., Pokrotniece K. Svešvārdu vārdnīca. Rīga: Jumava, 2005, 453. lpp.

Ibid., 284. lpp. 
Ir divi procesa virzītāji, kuru pienākumos ietilpst soda mērķa sasniegšana - prokurors un tiesa. Turklāt KL tiek deklarēti arī vairāki soda mērḳi, kas expressis verbis norādīti KL 36. pantā:

"Personai, kura izdarījusi noziedzīgu nodarījumu, var piespriest vienu no šãdiem pamatsodiem:

- brīvības atṇemšana;

- piespiedu darbs;

- naudas sods.

Bez pamatsoda notiesātajam var piespriest šādus papildsodus:

- mantas konfiskācija;

- izraidīšana no Latvijas Republikas;

- piespiedu darbs;

- naudas sods;

- tiesíbu ierobežošana;

- probācijas uzraudzība.”

Vienlaikus KL 36. panta otrajā daḷā noteikta prokurora kā procesa virzītāja saistība ar soda mērķa realizēšanu. Tas nozīmē arī saistību ar sodu politiku:

"Personai, kura izdarījusi kriminālpārkāpumu, mazāk smagu noziegumu vai smagu noziegumu, par kuru paredzēts brīvības atṇemšanas sods līdz pieciem gadiem, prokurors, sastādot priekšrakstu par sodu, var noteikt naudas sodu vai piespiedu darbu, kā arī papildsodus - tiesību ierobežošanu vai probācijas uzraudzību. Tātad iespēja prokuroram noteikt naudas sodu, piespiedu darbu, kā arī papildsodus - tiesību ierobežošanu un piespiedu darbu."

Savukārt vispārējie principi sodu noteikšanai ir iekḷauti KL 46. pantā, kur skaidrots: "Sodu nosaka tādā apmērā, kādu par izdarīto noziedzīgo nodarījumu paredz šā likuma sevišķās daļas attiecīgā panta sankcija, ievērojot likuma vispārīgās daļas noteikumus.

(2)Nosakot soda veidu, ņem vērā izdarītā noziedzīgā nodarījuma raksturu un radīto kaitējumu, kā arī vainīgā personību.

(3)Nosakot soda mēru, ņem vērā atbildību mīkstinošos un pastiprinošos apstāklıus.

(4)Brīvības atṇemšanas sodu par kriminālpārkāpumu un mazāk smagu noziegumu piemēro, ja soda mērḳis nav sasniedzams, nosakot kādu no attiecīgā panta sankcijā paredzētajiem vieglāka soda veidiem.”

Jāuzsver, ka KL pantu sankciju iezīme, kas raksturo likumdevēja akceptētu krimināltiesību politiku, ir tā, ka pantu sankcijās tiek paredzēti vairāki sodu veidi, kuri kardināli atškরiras soda bardzības kontekstā. Tā, piemēram, KL 175. panta pirmajā dậā noteikts, ka "par svešas kustamas mantas slepenu vai atklātu nolaupī̌sanu (zādzība) soda ar brīvỉbas atņemšanu uz laiku līdz diviem gadiem vai ar īslaicīgu brīvỉbas atṇemšanu, vai ar piespiedu darbu, vai ar naudas sodu”. Tātad tiesību normas piemērotājam ir radīta rīcības brīvība piemērot tādu sodu, kas ietilpst skalā no brīvības atṇemšanas lìdz diviem gadiem vai/un naudas sodu. Tik plaša soda iespējamïba rada nekonsekvences sodu piemērošanā par līdzīgiem noziedzīgiem nodarījumiem. Tādējādi soda piemērošanas procesā tiek radìta iespēja īstenot pārāk lielu individualizāciju atkarībā no apsūdzētā personības. Kriminālsodu politikai vajadzīgi skaidrāk noteikti kritēriji. 


\section{Sodu politika}

Log̣iski, ka ar tik dažādu soda sankciju iespējām nepārtraukti tiek diskutēts par sodu politiku, taču Latvijas apstākḷ̆os šis diskusijas pamatā saistītas ar kriminālsodiem. Tā, piemēram, vēl 2009. gadā Ministru kabinets izdeva rīkojumu par kriminālsodu politikas koncepciju. ${ }^{6}$ Koncepcijas vai sodu politikas maiñas pamatā bija saistītas ar sodu bardzību, noziedzīgu nodarījumu daudzējādību, atbildību mīkstinošiem un pastiprinošiem apstāklịem. Izmaiñas tika saistītas ar atsevišksu sodu veidu izslēgšanu no KL, kā arī likuma papildināšana ar jauniem soda veidiem. Šì sodu politikas reforma tika realizēta 2013. gadā, izdarot plašus grozījumus noziedzīgu nodarijumu sankcijās. ${ }^{7}$ Tomēr jāatzīmē, ka publiskās diskusijās joprojām dažbrīd dominē vienkāršots viedoklis par nepieciešamo sodu politiku - bargi sodi var atrisināt atsevišķu noziedzīgu nodarījumu novēršanu un apkarošanu. Autors tam nepiekrït, jo sodu bardzība attiecināma uz vardarbīgiem, sevišķi smagiem noziedzīgiem nodarījumiem, kuru rezultāts ir cilvēka nāve, smagi miesas bojājumi, vai vardarbīgi noziedzìgi nodarijumu pret nepilngadīgajiem. Šajā kontekstā autors iesaka vienmēr paturēt prātā spīdzināšanas un miesas sodus, ko cilvēce piedzīvojusi savas vēstures laikā, taču acīmredzams ir arī to rezultāts - lielākā daļa no noziedzīgiem nodarijumiem, kas tikuši sodīti ar miesassodiem un citiem bargiem sodiem, nav apkarota līdz pat šim laikam.

Tādējādi secināms, ka postulāts par bargākiem sodiem nav efektīvākais risinājums noziedzības prevencijai. Vienlaikus attīstās arī idejas par nepilngadīgo kriminālatbildības reformu. ${ }^{8}$ Jaunu KL grozijumu anotācijā tiek uzsvērts, ka 2013. gada kriminālsodu politikas reforma ir būtiski ietekmējusi sodu piemērošanas praksi. Tā liecina, ka reforma ir veicinājusi kriminālsoda - piespiedu darba - plašāku piemērošanu, līdztekus mazinot nosacìtu notiesāšanu. Kā tālākie posmi sodu politikā nepilngadīgajiem tiek izvirzīta grozījumu izdarišana KL, nosakot probācijas uzraudzību kā pamatsodu, piespiedu darba aizstāšanu ar sabiedrisko darbu un KL seviškās dalıas sankciju turpmāku grozišanu. Piemēri tiek minēti, lai atspoguḷotu, kādos virzienos mūsdienās attīstās sodu politika. Proti, pamatā tās ir sodu veidu izmaiņas un KL sevišķās daļas atseviškłu pantu sankciju grozijumi.

\section{Kriminālprocesa politika}

Autors uzskata, ka sodu politikā joprojām nav izdevies panākt personu vienlīdzības principa un vienveidīgu sodu īstenošanu praksē tieši tādēl, ka nav konsekvences sodu politikā un tiesu realizētajā praksē. Autora ieskatā, nepietiekami tiek diskutēts, kā ar sodu politikas iespējām varētu panākt soda neizbēgamïbas principa realizēšanu.

6 Par Kriminālsodu politikas koncepciju. Ministru kabineta rỉkojums 11.08.2010. rīkojums Nr. 475/LV 128(4320), 13.08.2010.

7 Grozījumi Krimināllikumā. LV likums. 12.12.2012. Latvijas Vēstnesis, 27.12.2012., Nr. 202(4805).

8 Likumprojekta "Grozījumi Krimināllikumā" sākotnējās ietekmes novērtējuma ziṇojums (anotācija). Pieejams:www.tm.gov.lv/files/11.../d/vadl/a/TMA/not_071118_KL_berni.doc [aplūkots 08.07.2019.]. 
Te vietā būtu izteikties par KPL vienkāršoto procesu, tai skaitā par vienošanās procesa un prokurora pozīcijas ietekmi uz sodu politiku. Tā KL 41. panta (2 $\left.{ }^{1}\right)$ daļā noteikts:

"Naudas sods nosakāms tādā Latvijas Republikā noteikto minimālo mēnešalgu apmērā, kāds tas ir sprieduma taisǐšanas dienā, norādot spriedumā šā naudas soda summu Latvijas Republikas naudas vienībās. Atbilstoši kriminālprocesuālajiem noteikumiem prokurors var piemērot ne vairāk kā pusi no šã panta otrajā dạ̦ā paredzētā maksimālā naudas soda apmēra, ievērojot Latvijas Republikā noteikto minimālo mēnešalgas apmēru dienā, kad sastādīts priekšraksts par sodu, un norādot savā priekšrakstā par sodu šā naudas soda summu Latvijas Republikas naudas vienībās." Tātad noteikti strikti nosacijumi, prokuroram piemērojot prokurora priekšrakstu par sodu.

Lìdzīgi var secināt arī par piespiedu darbu. KL 40. pantā - piespiedu darbs pirmajā daḷā noteikts:

"Piespiedu darbs kā pamatsods vai papildsods ir piespiedu iesaistī̌sana sabiedrībai nepieciešamajos darbos, ko notiesātais vai persona, kurai piespiedu darbs noteikts ar prokurora priekšrakstu par sodu, izcieš, veicot dzīvesvietas apvidū piespiedu darba izpildes institūcijas noteiktos darbus no pamatdarba vai mācībām brīvajā laikā un bez atlīdzības. Piespiedu darbu kā pamatsodu nosaka uz laiku no 40 līdz 280 stundām. Prokurors, priekšrakstā par sodu nosakot piespiedu darbu, var piemērot ne vairāk kā pusi no šajā pantā paredzētā maksimālā piespiedu darba ilguma. Piespiedu darbu kā papildsodu uz laiku no 40 līdz 100 stundām var noteikt personām, kuras notiesātas nosaciti."

Minētās KPL normas tiek citētas, lai argumentētu KPL saistību ar sodu politiku, jo KPL normas, kas saistītas ar apsūdzētā sadarbību ar procesa virzītāju, kriminālprocesuālā kārtỉbā arī ietekmē sodu politiku. KPL 21. pantā noteikts, ka persona, kurai ir tiesỉbas uz aizstāvību, var sadarboties ar kriminālprocesa veikšanai pilnvaroto amatpersonu, lai sekmētu krimināltiesisko attiecību noregulējumu:

“(2) Sadarbiba var izpausties:

1) vienkāršāka procesa veida izvēlē;

2) procesa norises veicināšanā;

3) citu personu izdarītu noziedzīgu nodarijumu atklāšanā.

(3) Sadarbība iespējama no kriminālprocesa uzsākšanas brīža līdz soda izpildei.”

Būtiskākais attiecībā uz sodu politiku ir vienkāršota procesa izvēle un sadarbības iespējamība ar procesa virzītāju līdz soda izpildei, tomēr svarīgi apzināties, kādas vēl ir KPL iespējas un kritēriji sodu politikas ietekmēšanai, jo tas ir pamats diskusijai par kriminālprocesa politiku. Tā KPL 420. panta pirmajā daļā ir noteikts:

"Ja persona izdarījusi kriminālpārkāpumu, mazāk smagu noziegumu vai smagu noziegumu, par kuru paredzēts brīvības atṇemšanas sods līdz pieciem gadiem, un prokurors, nnemot vērā izdarītā noziedzìga nodarījuma raksturu un radīto kaitējumu, personu raksturojošus datus un citus lietas apstākḷus, ir guvis pārliecỉbu, ka šai personai nevajadzētu piemērot brīvības atṇemšanas sodu, taču to nevar atstāt nesodìtu, viņ̌̌ var pabeigt kriminālprocesu, sastādot priekšrakstu par sodu. Prokurora priekšrakstu par sodu, ja persona izdarijusi smagu noziegumu, par kuru paredzēts brīvibas atñemšanas sods līdz pieciem gadiem, var sastādìt, ja tam piekrìt amatā augstāks prokurors." 
No KPL normas formulējuma izriet vairāki kritēriji. Prokurora priekšrakstu par sodu var piemērot par kriminālpārkāpumu, mazāk smagu noziegumu un smagu noziegumu, par kuru paredzēts brīvības atņemšanas sods līdz pieciem gadiem. Autora ieskatā gan, kriminālprocesa politikas kontekstā galvenais ir iezīmēti soda politikas kritēriji atkarībā no noziedzīga nodarījuma smaguma. Tomēr ir arī citi veidi, kā prokurors var ietekmēt sodu politiku - prokurora protesta iesniegšana. KPL 559. panta ceturtajā dalāā noteikts, ka lietu var iztiesāt rakstveida procesā, ja:

“1) apelācijas sūdzībā vai protestā ir izteikts lūgums tikai par piespriestā soda mīkstināšanu un ja prokurors vai persona, kuras intereses un tiesības sūdzība vai protests aizskar, pret to neiebilst; [..]

4) apelācijas sūdzībā vai protestā ir izteikts lūgums tikai par piespriestā soda mīkstināšanu un ja lieta pirmās instances tiesā izskatīta bez pierādījumu pārbaudes un piespriestais sods nav saistīts ar brīvïbas atṇemšanu, kas ilgāka par pieciem gadiem; [..]”

Secinājums ir- KPL ir normas, kas var ietekmēt sodu politiku, to skaitā krimināltiesību politiku, turklāt pamatā tā ir prokurora kā procesa virzìtāja iespēja ietekmēt šo politiku.

Ievērojami būtiskāka saistība ar sodu politiku ir iespējama vienošanās procesam. KPL 433. pantā noteikts pamats vienošanās piemērošanai.

“(1) Prokurors pēc savas paša, apsūdzētā un viṇa aizstāvja iniciatīvas var slēgt vienošanos par vainas atzišanu un sodu, ja ir noskaidroti apstākḷi, kas attiecas uz pierādīšanas priekšmetu, un apsūdzētais piekrīt viņam inkriminētā nodarījuma apjomam, kvalifikācijai, radītā kaitējuma novērtējumam un vienošanās procesa piemērošanai.

(2) Vienošanās procesu nevar piemērot, ja vienā kriminālprocesā ir vairāki apsūdzētie un vienošanos par vainas atzīšanu un sodu nevar piemērot visiem apsūdzētajiem."

Raksta autors joprojām uzskata, ka vienošanās process ir līgums starp valsti un apsūdzēto, ${ }^{9}$ kurā katrai pusei ir jāpilda savi pienākumi. Noteikti, KPL problēma ir, ka nav paredzēti skaidri kritēriji, kādu sodu piespriedīs tiesa un kādam būtu jābūt sodam, ja valsts pārstāvis - procesa virzītājs (prokurors vai tiesa) - vienojas par vainas atzǐ̌anu un sodu. No vienas puses, valsts nedrīkst uzspiest vienošanās procesu, bet, ja apsūdzētais atzīst vainu, kompensējis mantisko kaitējumu un piekrīt vienošanās procesa piemērošanai, valstij ir jānovērtē arī šāda apsūdzētā rīcība. Autors uzskata, ka zināmi soda noteikšanas principi vienošanās procesā būtu stimuls vienošanās procesa piemērošanai. Arī valsts nedrīkst "apkrāpt" vai "devalvēt" apsūdzētā labprātīgu gatavību atzìt vainu, atlīdzināt mantisko kaitējumu, pretī iegūstot mazāku sodu, nekā būtu piespriedusi tiesa, arī ja krimināllieta uz tiesu būtu nosūtīta vispārējā kārtībā un apsūdzētais atzìtu vainu un būtu gatavs atlīdzināt nodarìto mantisko kaitējumu. No valsts viedokḷa, tai jābūt efektīvai KL normu piemērošanai.

9 Sk. Maizītis J. Vai vienošanās process ir līgums? No: Juridiskās zinātnes teorētiskie un praktiskie problēmjautājumi. Juridiskās zinātnes doktorantu un zinātniskā grāda pretendentu III zinātniski praktiskās konferences rakstu krājums. LU: LU Akadēmiskais apgāds, 2012, 86. lpp. 
Padzilinātā pētniecībā autors ir noskaidrojis, ka sākotnēji Latvijā vienošanās process tika piemērots $5 \%$ gadījumu no uz tiesu nosūtītajām krimināllietām, tomēr gadu gaitā procentuālā dal̦a pakāpeniski ir augusi, un 2018. gadā uz tiesu vienošanās procesā nosūtīti 13,8 \% no visām krimināllietām. ${ }^{10}$ Šis ir viens no iemesliem, kāpēc ir vērts diskutēt par soda politiku vienošanās procesā.

\section{Sodu politika vienošanās procesā: skats uz ārpusi}

Pirmais un galvenais secinājums - KPL, kā arī citur nav noteikti kritēriji sodam, par kuru vienošanās procesā prokurors un apsūdzētais vienojas. Pamatā ir prakse, kas veidojas vienošanās procesa piemērošanas gaitā un līdz ar to ir l̦oti svārstīga un pretēja vienlīdzīgai sodu politikai. Tomēr autors norāda, ka vienveidīgas prakses nav arī tādās valstīs, kur vienošanās procesam ir būtiskāka nozīme kriminālprocesu pabeigšanā, piemēram, ASV. Vienlaikus tā vai citādi soda jautājumi šajās valstīs tiek regulēti precīzāk. Tas var būt likums, tās var būt vadlīnijas prokuroriem par soda izvēli vienošanās procesā vai kāds cits dokuments, tomēr kādas vadlīnijas vai instrukcijas pastāv.

Piemēram, Anglijas un Velsas valsts prokuroru kodeksā noteikts, ka ir šādas sodu politikas vadlīnijas. Kaut gan nav absolūti skaidrots, vai soda atlaide būtu jādod, vispārējā vadlīnija noteic, ka tādā gadījumā, ja cilvēks atzīstas noziegumā, atlaide ir viena trešdal̦a no iespējamā soda, bet tas ir arī atkarīgs no tā, kurā brīdī atzīšanās notiek. Proti, ja tas notiek pie pirmās iespējas, tā ir viena trešdaļa, ja tiesas prāvas datums ir noteikts - viena ceturtdaļa; ja tas notiek tiesas procesa laikā - atlaide ir viena desmitā daḷa. Tāpat saglabāts noteikums, ka tad, ja izdarīts noziedzīgs nodarījums, kuram ir obligāts minimālais sods, tad atlaide nedrīkst pārsniegt vienu piekto daļu.

Jāuzsver, ka prokuroru kodekss ir publisks dokuments, kuru akceptējis prokuratūras vadītājs, un tas nosaka prokuroru vispārīgos darbības principus lēmumu pieņemšanai krimināllietās. Tās ir vadlinnijas prokuroriem, kuras regulāri tiek papildinātas, respektējot grozījumus normatīvajos aktos un normu piemērošanu praksē. ${ }^{11}$ Būtiski ir tas, ka sods ir pakārtots kriminālprocesa laika aspektā - jo ātrāk vienošanās tiek panākta, jo mazāks sods. Prokuroru kodeksa vadlīnijas ir publiski pieejamas, līdz ar to arī zināmas apsūdzētajam un viṇa advokātam.

Nedaudz citāda pieeja ir Kanādā, tomēr arī tā ir saistīta ar vadlīnijām prokuroriem par sodu un vienošanās procesu. Kanādas federālo prokuroru rokasgrāmatā noteikts, ka gadījumā, ja noziedznieks atzīstas pastrādātajā noziedzīgajā nodarījumā, prokuroram ir pienākums izteikt piemērojamā soda piedāvājumu pēc iespējas ātrāk, turklāt jānosaka arī tas, cik ilgi šis piedāvājums ir spēkā. Ja ir liela iespējamo sodu variācija, prokuroram tiek ieteikts konsultēties ar kolẹgiem, lai saprastu no iespējamiem sodiem, kāda ir līdzšinējā prakse un piemērotākais sods konkrētajā situācijā. Jo smagāks un

10 Latvijas Republikas Prokuratūras darba rezultāti 2018. gadā. Pieejams: http://www.lrp.gov.lv/media/ Prokuraturas_darba_rezultati_2018.pdf [aplūkots 02.08.2019.].

11 The Code for Crown Prosecutors. Pieejams: www.cps.gov.uk/legal-guidance/sentencing-overview [aplūkots 08.07.2019.]. 
bīstamāks ir noziegums, jo svarīgāk ir konsultēties. ${ }^{12}$ Arī Kanādas federālo prokuroru rokasgrāmata ir publiski pieejama; un procesa dalībniekiem vadlīnijas līdz ar to ir zināmas. Kanādā prokurora pienākums tiek saistīts nevis ar atzīšanās ātrumu kā Anglijā un Velsā, bet ar atzǐšanās ātruma novērtēšanu un atbildes sniegšanu uz prokurora izteikto piedāvājumu. Vienlaikus arī apsūdzētajai personai tiek dots neliels terminš̌ piedāvājuma izvērtēšanai. Salīdzinot minētos piemērus ar Latvijas apstākḷiem, noteikti visstrīdīgākā būtu vadlīnija, kas noteiktu nepieciešamās konsultācijas ar kolēgiem, ja ir izdarìts smags vai bīstams noziegums. KPL ir noteikta liela procesa virzìtāju patstāvība lēmumu pien,emšanā, tātad neatkarība. Taču, ja godīgi pavērtējam praksi, vai tad ir tā, ka, piemēram, prokurors nekonsultējas ar kolēgiem par procesuālu lēmumu pieņemšanu un arī sodu?

\section{Kopsavilkums}

1. Pēc autora ieskata, kriminālprocesa politiku ir nepieciešams definēt šādi: kriminālprocesuālās kārtības politika ir KPL noteiktie vispārējie pamatprincipi, KPL normas, kas attiecas uz soda mērķa sasniegšanu.

2. Vienošanās procesa gaitā noteiktā vienošanās par sodu ir daļa no kriminālprocesuālās soda politikas.

3. Nepieciešams izstrādāt publiski pieejamus kritērijus sodam, par kuru iespējama vienošanās. Kritēriji saistāmi ar noziedzīga nodarījuma smagumu, kriminālprocesa stadiju, kurā notiek vainas atzī̌sana. Jābūt iespējami skaidri definētam mehānismam, kāds būs tiesas noteiktais sods, ja netiek îstenots vienošanās process.

4. Soda izvēles principi iespējami skaidri jānosaka vai nu KPL, vai vadlīnijās prokuroriem par sodu vienošanās procesā. Ja šāda ideja tiek atbalstīta, citu valstu pieredze rāda, ka KPL normas vai vadlīnijas ir diskutējamas un salīdzinoši viegli formulējamas.

\section{BIBLIOGRĀFIJA}

1. Baldunčiks L., Pokrotniece K. Svešvārdu vārdnīca. Rīga: Jumava, 2005.

2. Maizītis J. Vai vienošanās process ir līgums? No: Juridiskās zinātnes teorētiskie un praktiskie problēmjautājumi. Juridiskās zinātnes doktorantu un zinātniskā grāda pretendentu III zinātniski praktiskās konferences rakstu krājums. LU: LU Akadēmiskais apgāds, 2012, 86.-91. lpp.

\section{Likumi un normativie akti}

3. Grozījumi Krimināllikumā. LV likums. 12.12.2012. Latvijas Vēstnesis, 27.12.2012. Nr. 202(4805).

4. Kriminālprocesa likuma koncepcija, 12.06.2001. Jurista vārds, 26.06.2011., Nr. 20.

12 Public Prosecution Service of Canada. Public Prosecution Service of Canada Deskbook (2014). Pieejams: https://www.ppsc-sppc.gc.ca/eng/pub/fpsd-sfpg/index.html [aplūkots 08.07.2019.]. 
5. Krimināllikums: Latvijas Republikas likums. Latvijas Vēstnesis Nr. 199/200 (1260/1261) 08.07.1998.[13.03.2019. red].

6. Kriminālprocesa likums: Latvijas Republikas likums. Latvijas Vēstnesis, 11.05.2005. Nr. 74 (3232). Likumprojekta “Grozījumi Krimināllikumā” sākotnējās ietekmes novērtējuma ziņojums (anotācija).

7. Par Kriminālsodu politikas koncepciju. Ministru kabineta rīkojums 11.08.2010. rīkojums Nr. 475/LV 128(4320), 13.08.2010. Pieejams:www.tm.gov.lv/files/l1.../d/vadl/a/TMA/ not_071118_KL_berni.doc [aplūkots 08.072019].

8. Latvijas Republikas Prokuratūras darba rezultāti 2018. gadā http://www.lrp.gov.lv/media/ Prokuraturas_darba_rezultati_2018.pdf [aplūkots: 02.08.2019.]

9. The Code for Crown Prosecutors. Pieejams: www.cps.gov.uk/legal- guidance/sentencingoverview. [aplūkots 08.07.2019.].

10. Public Prosecution Service of Canada. Public Prosecution Service of Canada Deskbook (2014). Pieejams: https://www.ppsc-sppc.gc.ca/eng/pub/fpsd-sfpg/index.html [aplūkots 08.07.2019.]. 